\title{
Regional Economic, Corporate Characteristics, Social Responsibility Report and Environmental Accounting Information Disclosure
}

\author{
Yongchen $\mathbf{L i}^{1}$ \\ ${ }^{1}$ North China Electric Power University, \\ Baoding 071003 \\ Yueyi Tian ${ }^{1}$ \\ ${ }^{1}$ North China Electric Power University, \\ Baoding 071003 \\ Zhiyuan Liu' ${ }^{1}$ \\ ${ }^{1}$ North China Electric Power University, \\ Baoding 071003
}

\begin{abstract}
From the perspective of macroeconomic developments outside the enterprise level and internal microstructure features, examining the disclosure of environmental accounting information listed in Shanghai and Shenzhen ferrous metal smelting and rolling processing industry of the status, through empirical research and analysis of the environmental accounting information disclosure factors,it indicates that the development of enterprise size and enterprise social responsibility report positive relationship with its environmental accounting information disclosure level.The final recommendations of corporate environmental responsibility into internal systems construction,national,social and regulatory authorities should improve the legal supervision of polluting industries.
\end{abstract}

Keywords:regional economic disparity;enterprise characteristics;social responsibility report; environmental accounting information disclosure

\section{Introduction}

In recent years, mass incidents around environmental issues one after another, in the economic, social and political triple pressure, China's response to environmental pollution into the cost of debt servicing. Known as "the history of the most stringent" new "environmental law" since January 1,
2015 will be implemented, an increase from 47 to 70 legislative provisions on environmental pollution more stringent corporate governance requirements.Environmental pressures facing the steel industry is growing, energysaving and environmental protection will face more stringent regulation.

In this environment, corporate environmental accounting information disclosure is necessary. However, From the current situation of studies, and there is not much to study the situation through macro industry in the field of microscopic research. This paper from the regional economic, business and social responsibility report features three perspectives, examine its impact on the environmental accounting information disclosure.

\section{Theoretical analysis and research hypothesis}

\subsection{Regional Economic Development and Environmental Accounting Information Disclosure}

The development gap between China's eastern Midwest are historical issues, GDP of the region in 2013 as an example , ranking first in Guangdong province GDP was 6.23 trillion yuan, and 0.08 trillion yuan in Tibet region ranked last $77-$ fold difference.From the point of view of international developments,environmen- 
tal accounting information disclosure level in Europe and America and other developed countries is significantly higher than China's.

Thus this paper hypothesis H1: Regional economic development and corporate environmental accounting information disclosure level positive.

\subsection{Enterprise Characteristics and Environmental Accounting Information Disclosure}

1) The enterprise scale and environmental accounting disclosures

The larger the scale, which will be subject to the higher degree of social concern, subject to public pressure will be greater, and therefore the internal management of political sensitivity will be significantly higher than SMEs.

Thus this paper hypothesis H2: firm size and corporate environmental accounting information disclosure levels positively correlated.

2) Business performance and environmental accounting information disclosure

According to the financial management of the signaling theory, enterprises can deliver business-related information to the outside world through the financial disclosure.

Thus this paper hypothesis H3: enterprise performance level and the level of corporate environmental accounting information disclosure related.

3) Debt and environmental accounting information disclosure

High debt levels of the enterprise may be inclined to disclose their environmental accounting information to indicate a low risk business environment, in order to obtain more financing to financial institutions.

Thus this paper hypothesis H4: the level of corporate debt and corporate environmental accounting information disclosure level positive.

\subsection{Corporate Social Responsibility Report and} Environmental Accounting Information Disclosure

Most corporate social responsibility report will be made on the environmental accounting information disclosed in detail.
Thus this paper hypothesis H5: corporate social responsibility report positively correlated with the level of corporate environmental accounting information disclosure.

\section{Sample Design and Methods Summary}

\subsection{Sample selection and data sources}

According to the CSRC industry sector, the choice of the CSI 2013 Annual Report and Social Responsibility Report listed ferrous metal smelting and rolling processing industry (Industry Code C31) 31 listed companies in the sample, which is mainly related to iron and steel smelting industry and processing. Data used herein are derived from the Shenzhen Stock Exchange website, Shanghai Stock Exchange Web site and CSMAR database.

\subsection{Preliminary Situation Analysis of Environmental Accounting Information Disclosure}

31 in Shanghai and Shenzhen listed ferrous metal smelting and rolling processing industry in 2013 annual reports of listed companies and their social responsibility report disclosure of environmental accounting information as shown in Table 3-1, we can see that most of the project is "Environmental Statement, Target and effectiveness ", accounting for $74.19 \%$ of the total sample;the disclosure of fewer items as" energy conservation or environmental protection investment expenditure ", shows China's listed companies are lack of environmental accounting information. 
Table 3-1 Environmental Accounting Information Disclosure

\begin{tabular}{|c|c|c|}
\hline \multirow{2}{*}{ Projects } & \multicolumn{2}{|c|}{ Enterprises } \\
\hline & Number & Percentage \\
\hline $\begin{array}{l}\text { Environmental Statement, } \\
\text { objectives and } \\
\text { achievements }\end{array}$ & 23 & $74.19 \%$ \\
\hline $\begin{array}{l}\text { Environmental regulation } \\
\text { compliance statements }\end{array}$ & 19 & $61.29 \%$ \\
\hline $\begin{array}{l}\text { Recycling economy or } \\
\text { saving }\end{array}$ & 22 & $70.97 \%$ \\
\hline $\begin{array}{l}\text { Emission type, quantity, } \\
\text { concentration }\end{array}$ & 15 & $48.39 \%$ \\
\hline $\begin{array}{l}\text { Consumption of resources } \\
\text { and energy structure }\end{array}$ & 16 & $51.61 \%$ \\
\hline Environmental incidents & 10 & $32.26 \%$ \\
\hline $\begin{array}{l}\text { Energy conservation or } \\
\text { environmental protection } \\
\text { investment }\end{array}$ & 9 & $29.03 \%$ \\
\hline $\begin{array}{l}\text { Environmental protection- } \\
\text { related projects }\end{array}$ & 17 & $54.84 \%$ \\
\hline $\begin{array}{l}\text { Environmental technology } \\
\text { spending }\end{array}$ & 18 & $58.06 \%$ \\
\hline Production waste recycling & 14 & $45.16 \%$ \\
\hline Governance fired & 12 & $38.71 \%$ \\
\hline $\begin{array}{l}\text { Obtain ISO14001 } \\
\text { certification }\end{array}$ & 6 & $19.35 \%$ \\
\hline Environmental monitoring & 10 & $32.26 \%$ \\
\hline Environmental risks & 20 & $64.52 \%$ \\
\hline Punishment information & 1 & $3.23 \%$ \\
\hline $\begin{array}{l}\text { Construction and operation } \\
\text { of environmental protection } \\
\text { facilities }\end{array}$ & 14 & $45.16 \%$ \\
\hline $\begin{array}{l}\text { Be rewarded for protecting } \\
\text { environment }\end{array}$ & 5 & $16.13 \%$ \\
\hline $\begin{array}{l}\text { Other environmental } \\
\text { information }\end{array}$ & 8 & $25.81 \%$ \\
\hline
\end{tabular}

\subsection{Model settings and variable design}

1. model specification

Established according to the following regression model $\mathrm{H} 1 \sim \mathrm{H} 5$, such as (1) formula.

Environmental accounting information disclosure index $=\beta_{0}+\beta_{1}$ level of regional economic development $+\beta_{2}$ social respon-

sibility report $+\beta_{3}$ enterprise scale $+\beta_{4} \mathrm{deb}$ -

$\mathrm{T}$ levels $+\beta_{5}$ financial results $+\mu$

Wherein, $\beta_{0} \sim \beta_{5}$ coefficients, $\mu$ is the error term.

Specific models are:
IEIEA $=\beta_{0}+\beta_{1} X_{1}+\beta_{2} X_{2}+\beta_{3} X_{3}+\beta_{4} X_{4}+\beta_{5} X_{5}$

$+\mu$

Table 3-2 Argument Definition Table

\begin{tabular}{|c|c|c|c|}
\hline Project & $\begin{array}{c}\text { Argument } \\
\text { meaning }\end{array}$ & $\begin{array}{l}\text { Sym- } \\
\text { bol }\end{array}$ & Definitions \\
\hline $\begin{array}{l}\text { Level of } \\
\text { regional } \\
\text { economic } \\
\text { develop- } \\
\text { ment }\end{array}$ & $\begin{array}{l}\text { GRP in } \\
2013 \\
\text { ranked }\end{array}$ & $X_{1}$ & $\begin{array}{l}\text { Gross national } \\
\text { production by } 2013 \\
\text { the region ranked } \\
\text { highest in GDP } \\
\text { assignment } 1 \text {, the } \\
\text { lowest GDP in the } \\
\text { region assignment } \\
31 \text {. }\end{array}$ \\
\hline \multirow{3}{*}{$\begin{array}{l}\text { Enterprise } \\
\text { Characte- } \\
\text { ristics }\end{array}$} & $\begin{array}{l}\text { Enterp- } \\
\text { rise scale }\end{array}$ & $X_{2}$ & $\begin{array}{l}\text { The natural } \\
\text { logarithm of the total } \\
\text { business } \\
\text { characteristics of } \\
\text { corporate assets }\end{array}$ \\
\hline & $\begin{array}{c}\text { Debt } \\
\text { levels } \\
\end{array}$ & $X_{3}$ & $\begin{array}{l}\text { Corporate assets and } \\
\text { liabilities }\end{array}$ \\
\hline & $\begin{array}{c}\text { Financial } \\
\text { results }\end{array}$ & $X_{4}$ & $\begin{array}{l}\text { Corporate financial } \\
\text { performance ROE }\end{array}$ \\
\hline $\begin{array}{l}\text { Social } \\
\text { Respon- } \\
\text { sibility } \\
\text { Report }\end{array}$ & $\begin{array}{l}\text { Whether } \\
\text { report is } \\
\text { published }\end{array}$ & $X_{5}$ & $\begin{array}{l}\text { Dummy variable, if } \\
\text { released an } \\
\text { assignment, or an } \\
\text { assignment } 0\end{array}$ \\
\hline
\end{tabular}

2. The dependent variable design

Based on Listed Companies 2013 Annual Report and Social Responsibility Report manual collection of data referring to the "Shanghai Stock Exchange listed companies Environmental Information Disclosure Guidelines" required disclosures be aggregated classification, environmental accounting information of listed companies to disclose the minutes to 18.(Ie Table 3-1 Disclosure Project)

In all listed companies in 2013 annual report and social responsibility report, each one were assigned to disclose one point, the highest score of 18 points, the lowest score of 0 points, in order to measure environmental accounting information level.IEIEA can be used as model (1.1) 's explanatory variables, listed companies received higher scores indicate more adequate environmental accounting information disclosure of the company. 


\section{Demonstration Test and Analysis}

\section{1. variable correlation test}

Correlation test results are shown in Table 4-1.

Table 4-1 variable correlation coefficient

\begin{tabular}{|c|c|c|c|c|c|c|}
\hline & & $X$ & $X_{\Omega}$ & $X$, & $X$. & $X_{-}$ \\
\hline & Poarso & 1 & 2.54 & 316 & 337. & -325 \\
\hline \multirow[t]{3}{*}{$X_{1}$} & Sig. & & .168 & .084 & .068 & .075 \\
\hline & $N$ & 31 & 31 & 31 & 31 & 31 \\
\hline & Pearso & .254 & 1 & $.557^{*}$ & .172 & -.223 \\
\hline \multirow[t]{3}{*}{$X_{2}$} & Sig. & .168 & & .001 & .354 & .228 \\
\hline & $N$ & 31 & 31 & 31 & 31 & 31 \\
\hline & Pearso & 316 & $557^{* *}$ & 1 & 353 & - \\
\hline \multirow[t]{3}{*}{$X_{3}$} & Sig. & .084 & .001 & & .051 & .028 \\
\hline & $N$ & 31 & 31 & 31 & 31 & 31 \\
\hline & Poarso & 337 & 177. & 353 & 1 & -295 \\
\hline \multirow[t]{3}{*}{$X_{4}$} & Sig. & .068 & .354 & .051 & & .107 \\
\hline & $N$ & 31 & 31 & 31 & 31 & 31 \\
\hline & Pearso & -375 & -2.33 & - & -9.95 & 1 \\
\hline \multirow[t]{2}{*}{$X_{5}$} & Sig. & .075 & .228 & .028 & .107 & \\
\hline & $N$ & 31 & 31 & 31 & 31 & 31 \\
\hline
\end{tabular}

Test results show whether a company released a social responsibility report $\left(X_{2}\right)$ and firm size $\left(X_{3}\right)$ correlation coefficient of 0.557 , both at the 0.01 level of strong correlation, but little overall impact. Company size $\left(X_{3}\right)$ and corporate performance level $\left(X_{5}\right)$ two variables correlation coefficient of -0.395 , with a slight correlation. The correlation coefficient between the rest of the explanatory variables are less than 0.5 , so that the model (1.1) is small there may be multicollinearity between the explanatory variables.

\subsection{Variable Multiple linear regression analysis}

Model (1.1) regression results are shown in the table4-2.
Table 4-2 Regression coefficients

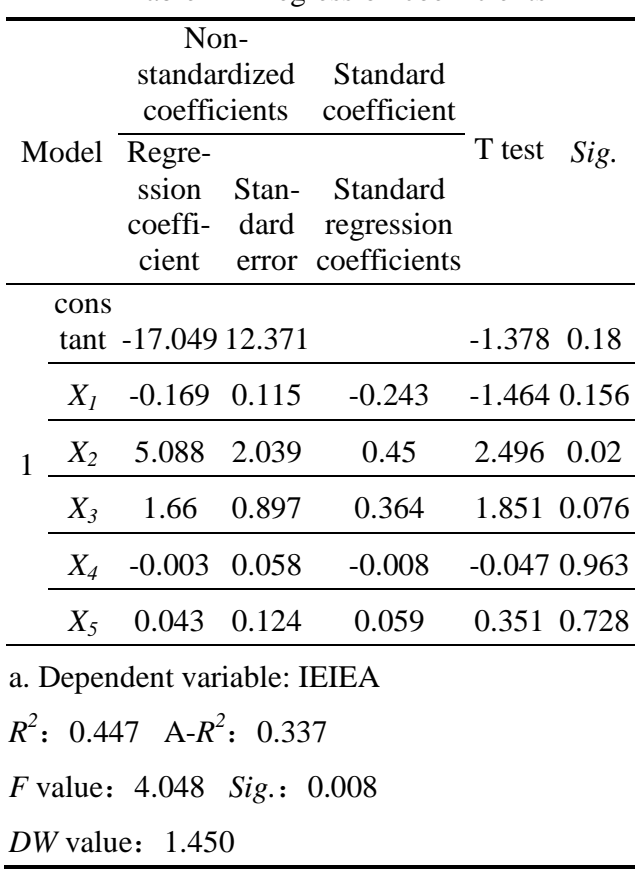

As it can be seen from the table, corporate social responsibility report positively correlated with the level of corporate environmental accounting information disclosure. At the same time it can be seen that firm size positively correlated with disclosures . By assuming that the rest of the explanatory variables were tested, corresponding $\mathrm{H} 1$, H3, H4 suppose it can not set up.

Thus regression model derived regression equation: IEIEA $=5.088 X_{2}+1.66 X_{3}$

\section{Conclusions}

Results of this study showed that:

1) The level of disclosure of environmental information of the ferrous metal smelting and rolling processing industry of listed companies is low, while there is a lack of standardized information disclosure,etc.;

2) Environmental accounting information of listed companies in the industry to disclose has nothing to do with the level of regional economic development, probably due to late development in western China, have begun to focus in the development of beginning to build investment and environmental responsibi-

lity of environmental protection; 
3) The industry environmental accoun-

ting information disclosure of listed companies there is a positive relationship between the level associated with their size, but with corporate debt levels and no significant correlation results of operations;

4) The business environment accounting information disclosure of listed companies and whether the enterprise level social responsibility report has a significant positive correlation, indicating that develop and promote corporate social responsibility report is an important means to promote corporate environmental accounting disclosure of information.

\section{Recommendations}

- In order to achieve the sustainable development of our society and economy, I recommend the following departments:

1) The government should focus on strengthening corporate environmental accounting information disclosure regulation, While developing relevant disclosure rules, guide enterprises from different aspects of the disclosure.

2) the public in public opinion on corporate environmental accounting information disclosure, to carry out corporate environmental accounting information disclosure investigation.
3) SFC authorities and stock exchanges should strengthen supervision and guidance for environmental accounting information disclosure of listed companies.

4) The enterprise itself should continue to strengthen environmental protection system construction. In the ferrous metal smelting and rolling processing industry enterprises,social responsibility report released less than half, which have not an environmental liability regime for construction and improvements.It shows that China's heavy polluting industries for accounting and disclosure of environmental accounting information based mostly outside pressure, not a sense of responsibility to the environment into their own systems. Therefore, improving the environment for their own sense of responsibility, improve environmental accounting information disclosure is fundamental.

\section{References}

[1] Jianming Wang, "Correlation researc-h of environmental information disclosure, industry differences and outside pressure," Accounting research, pp. 54-62, 2008.

[2] http://www.cninfo.com.cn. 